\title{
EFFECTS OF ANTI HYPERTENSIVE AGENT AND SMOKING ON SEXUAL DYSFUNCTION AMONG MALES OF REPRODUCTIVE AGE IN DELI SERDANG, NORTH SUMATERA
}

\author{
Nurdiana Manurung \\ Study Program in Reproductive Health, Masters Program in Public Health, \\ Faculty of Public Health, Universitas Sumatera Utara
}

\begin{abstract}
Background: Older antihypertensive drugs (central-acting, $\beta$ blockers, diuretics) have traditionally been considered to cause erectile dysfunction, while the newer ones (calcium antagonists, angiotensin-converting enzyme [ACE] inhibitors, and angiotensin receptor blockers [ARBs]) have either neutral effects or may even be beneficial with respect to sexual function. In addition to the well-established harmful effects of smoking (i.e coronary artery disease and lung cancer), the past three decades have led to a compendium of evidence being compiled into the development of a relationship between cigarette smoking and erectile dysfunction. Empirical studies into this issue are scanty in Indonesian male population. This study aimed to determine effects of anti hypertensive agent and smoking on sexual dysfunction among males of reproductive age in Deli Serdang, North Sumatera.

Subjects and Method: This was a cross sectional study carried out at Puskesmas (Community Health Center) Pancur Batu, Deli Serdang, North Sumatera. A sample of 128 males of reproductive age who visited Puskesmas Pancur Batu was selected for this study. The dependent variable was sexual dysfunction. The independent variables were use of anti hypertensive drug and smoking. Data on use of anti hypertensive drug were taken from the medical record. The other variables were measured by questionnaire. The data were analyzed by a multiple logistic regression.

Results: Use of anti hypertensive drug $(\mathrm{OR}=4.11 ; \mathrm{p}=0.045)$ and smoking $(\mathrm{OR}=$ $5.65 ; \mathrm{p}=0.022$ ) were associated with an increased risk of sexual dysfunction.

Conclusion: Use of anti hypertensive drug and smoking are associated with an increased risk of sexual dysfunction.
\end{abstract}

Keywords: anti hypertensive drug, smoking, sexual dysfunction.

\section{Correspondence:}

Nurdiana Manurung. Study Program in Reproductive Health, Masters Program in Public Health, Faculty of Public Health, Universitas Sumatera Utara, Medan, North Sumatera. Email: nurdianamanurung@gmail.com. Mobile: 085261335333 